\title{
ДИАЛЕКТИЧЕСКАЯ КОНЦЕПЦИЯ РАЗВИТИЯ ПОЛИТИЧЕСКОЙ ПРЕСТУПНОСТИ В РОССИИ
}

\begin{abstract}
Аннотация: в работе рассматриваются вопросы, характеризующие состояние и динамические изменения политической преступности в России в соответствии с правовыми, доктринальными и бытовыми представлениями о ней и её разновидностях, начиная с Киевской Руси и заканчивая концом ХХ века. На основе историко-правовых источников автор выделяет два вида политической преступности - криминальное политическое насилие и политическая преступность не сопряженная с применением насилия, которые сохраняются и в современном российском обществе. При этом данные виды политической преступности постоянно изменяют свои качественные и количественные показатели, то ярко проявляются одни виды и угасают другие, то картина меняется на противоположную, под воздействием различных групп объективных социальных факторов.
\end{abstract}

Ключевые слова: Юриспруденция, политическая преступность, политическая криминология, заговор, бунт, политическое преступление, политическое насилие, политический терроризм, тоталитарная преступность, террор

П олитическая преступность как массовое негативное социально-правовое явление, заключающееся в противоправном получении, сохранении, распределении или утраты политической власти в обществе, существовало во все времена и у всех народов, существует она и в современном мире. Другое дело, что в одно и то же время в одних государствах официальными органами власти, их должностными лицами, политиками, представителями общественности и средств массовой коммуникации ее существование признается, в других ее наличие - отвергается. Однако, невзирая на официальное признание или отрицание политической преступности в обществе - она реально существует. Под воздействием сочетания различных групп социально-политических, экономических, идеологических и иных факторов политическая преступность постоянно изменяет свои формы, трансформируется из одного вида в другой, приспосабливается к новым социальным условиям политической жизни и неумолимо проявляется и распространяется в обществе, паразитируя на его пороках.

В древние времена политическая преступность проявлялась через множество различных по своему содержанию противоправных деяний, направленных против жизни, здоровья, имущества, политической репутации руководителей государства (государей), наследников престола, их близкого окружения, общественного спокойствия и безопасности государства. ${ }^{1}$ В более поздние периоды,

\footnotetext{
${ }^{1}$ Боатар. Лекции по уголовному праву и судопроизводству. Книга 3: Преступления против общества и государства / Пер. с франц. // Судебный журнал. - 1875. - Сентябрь - Октябрь. - С.276; Есипов Г.В. Люди старого века. Разсказы из дел Преображенского Приказа и Тайной Канцелярии. - СПб., 1880. C.74; Eсипов В.В. Уголовное уложение 1903 года, его характер и содержание. - Варшава, 1903. - С.64-71; Калашников И.
}

по мнению отечественных и зарубежных специалистов в области права, политическая преступность трансформировалась в негативное социально-правовое явление, которое постоянно и системно проявлялось в различных по своему содержанию противоправных деяниях. Одни из них считали, что политическая преступность состоит из совокупности уголовно-наказуемых деяний, совершаемых против политических прав индивидов. ${ }^{2}$ Другие видели политическую преступность во множестве противоправных деяний, совершенных по политическим мотивам ${ }^{3}$ или для достижения политических целей. ${ }^{4}$ Третьи рассматривали политическую преступность значительно шире, как систематически проявляющуюся совокупность, как правило, тяжких противоправных уголовно-наказуемых деяний, посягающих на существующий порядок государственного устройства, главу государства, его представителей (назначаемых им чиновников) и политические права

Об устройстве судебно-уголовной власти в Греции и Риме. - СПб., 1850. - С.38; Штиглии А.Ю. Исследования о выдаче преступников. - СПб., 1882. - С.74; Никольский Д.П. О выдаче преступников по началам международного права. - СПб., 1884. - С.170; Ломброзо Ч., Ляски Р. Политическая преступность и революция по отношению к праву, уголовной антропологии и государственной науке / Предисл. проф. И.А. Исаева. - СПб., 2003. - С.374; Гроссе Ф. К вопросу о природе политических преступлений // Проблемы марксизма. Сборник второй: Проблема преступности / Под ред. и с предисловием Я.С. Розанова. - Киев, 1924. - С.63; Викторский Е.П. История смертной казни в России и современное её состояние. - М., 1912. - С.381-396.

${ }^{2}$ Фейгин Я. Выдача политических преступников // Журнал гражданского и уголовного права. - 1884. - №4. - С.59-60.

${ }^{3}$ Никольский Д.П. Указ. раб. - С.163.

4 Эйхельман $O$. Заметки из лекций по международному праву. Киев, 1889. - С.42. 
граждан. ${ }^{5}$ Четвертые, анализируя реальное положение дел в политической жизни некоторых государств, полагали, что к политической преступности относятся политические деяния, не представляющие общественной опасности для государства и общества, но необоснованно запрещенные под страхом уголовного наказания, как, например, чтение книг политического содержания ${ }^{6}$ или оппозиционная политическая деятельность, не связанная с общественно опасным поведением и негативными для государства и общества последствиями. ${ }^{7}$

Политическая преступность как наиболее опасный и вредоносный вид социальной патологии довольно часто и разнообразно проявлялась в российском обществе на различных исторических этапах его развития. Отечественным историкам она известна с древнейших времен. Изначально российская политическая преступность наиболее ярко и часто проявлялась и показывала свой разрушительный потенциал в различных насильственных формах политической борьбы за княжеский престол. В результате борьбы за политическую власть в российском государстве наиболее сильным или коварным претендентом на нее производилось противоправное устранение или отстранение основных претендентов. Жертвами политических убийств, ложных измышлений, доносов, злоупотреблений властью и иных преступлений становились близкие лица бывшего или действующего главы государства: его братья и сестры, дети и родители. Ради сохранения или приобретения власти допускалось убийство своих близких родственников; отцеубийство, братоубийство, женоубийство, детоубийство, совершаемые хладнокровно ${ }^{8}$ и расчётливо. Проведенные исследования отечественных специалистов-историков свидетельствуют, что в нашей стране, начиная с Киевской Руси и по настоящее время, уровень насильственной смерти руководителей государства составил 28 процентов. ${ }^{9}$ Однако только внутригосударственными политическим террором и терроризмом либо политическими убийствами и иными видами преступлений не ограничивалось проявление

5 Лист Ф. Международное право в схематическом изложении. - Юрьев, 1909. - С.319; Карнович Е.П. Очерки наших порядков административных, судебных и общественных. - СПб., 1873. C.430-491

${ }^{6}$ Каутский К. Природа политических преступлений. - Киев, 1905. - C.7.

${ }^{7}$ Каутский К. Генезис политических преступлений // Проблемы марксизма. Сборник второй: Проблемы преступности / Под ред. и с предисловием Я.С. Розанова. - Киев, 1924. - С.47.

${ }^{8}$ Тард Г. Преступник и преступление. Сравнительная преступность. Преступления толпы / Сост. и предисл. В.С. Овчинского. - M., 2004. - C.117.

${ }^{9}$ Галкин Е.Б. Некоторые историко-социальные черты российской монархии // Социологические исследования. - 1998. - №5. C.14-15. политической преступности в историческом развитии российского общества. Политическая преступность, порождаемая сугубо внутренними причинами, активно проявлялась и во внешнеполитической деятельности высших должностных лиц российского государства.

Действия русских князей в целях расширения подвластных территорий и увеличения объемов властных полномочий не отличались от деятельности глав европейских государств в выборе средств и методов для достижения политических целей. Они также вели кровопролитные междоусобные войны, осуществляли заговоры с целью насильственного противоправного захвата власти и присоединения территории, через своих лазутчиков призывали к вооруженным мятежам и массовому неповиновению население сопряженных княжеств. Политическая преступность в древнерусском государстве проявлялась, как правило, именно в указанных выше противоправных насильственных формах политической борьбы. Однако некоторые отечественные исследователи отмечают и иные формы проявления политической преступности в древнем российском обществе. По их мнению, к таким деяниям следует относить и преступления, направленные не только против князя, но и против безопасности государства в форме государственной измены («крамолы»), связанной с переходом «княжьего» человека на сторону действительного или предполагаемого политического либо военного противника. ${ }^{10}$ По мнению известного российского правоведа конца XIX - начала XX веков Г.Г. Тельберга, формой политической преступности являлось противоправное участие поданных в восстании против главы государства или назначенных им должностных лиц, либо в недоносительстве, подстрекательстве, попустительстве или пособничестве в этих деяниях, а также укрывательство политических преступлений и преступников. ${ }^{11}$ Как правило, специалисты в области истории отечественного государства и права отмечают восстания населения против своих руководителей в Киеве в 1067 году против князя Изяслава, восстание в Белоозере в 1071 году, киевское восстание 1113 года и другие. ${ }^{12}$

Массовые вооруженные восстания (бунты и мятежи), направленные против внешней или внутренней политики высших должностных лиц государства и их представителей, происходившие в различных регионах мира, еще в

\footnotetext{
${ }^{10}$ Владимирский-Буданов М.Ф. Обзор истории русского права. Ростов - на - Дону, 1995. - С.342.

${ }^{11}$ Тельберг Г.Г. Система государственных преступлений в уложении Царя Алексея Михайловича // Журнал министерства юстиции. 1911. - №5. - С.146, 155; Его же. Рецензия на книгу: Новомбергский Н.Я. Слово и дело государевы. Том 1. - М., 1911. // Вопросы права. - 1911. - Кн.7. - №3. - С.181.

${ }^{12}$ История государства и права СССР: Учебник. Часть 1 / Под ред. Ю.П. Титова. - М.,1988. - С.71.
} 


\section{Право и политика 2 (158) 2013}

начале XIX века привлекли внимание отечественных и зарубежных исследователей в различных областях гуманитарного знания. ${ }^{13}$ Такое внимание обеспечивало несколько взаимосвязанных и взаимообусловленных объективных социальных факторов. Во-первых, частота вооруженных восстаний населения против своих руководителей в различных государствах. Во-вторых, тяжесть наступающих в результате совершения восстаний негативных социальных последствий для государства и общества. В-третьих, неэффективность принимаемых государством, его органами, должностными лицами и обществом специальных, как правило, карательных мер по противодействию вооруженным восстаниям и восставшим слоям населения.

Правоведами эти схожие по объективной стороне противоправные деяния были выделены в системе политических преступлений в самостоятельный вид. Этот особый вид организованных политических преступлений ${ }^{14}$ был назван известным отечественным правоведом XIX века профессором П.П. Пусторослевым - бунтовским. ${ }^{15}$

Статистический анализ состояния криминального политического насилия в Российской Империи отечественными специалистами стал активно использоваться лишь начиная со второй четверти XIX века. За период с 1827-го по 1915 год этот вид противоправного поведения в политической сфере жизни российского общества анализировался и интерпретировался как отечественными специалистами в области криминальной статистики, ${ }^{16}$ так

\footnotetext{
${ }^{13}$ См., например: Описание бунта бывшего в Китае в 1813 году // Дух журналов или Собрание всего, что есть лучшего и любопытнейшего во всех других Журналах по части Истории, Политики, Законодательства, Правосудия, Государственного Хозяйства, Литтературы, разных Искусств, Сельского Домоводства и проч. - 1819. - Кн.10: Архив истории и политики. - С.87-118; Как судить о всеобщих смятениях в Европе, а особенно в Англии? (Политический разговор) // Там же. - Кн.19. - С.119-142; О мятежах лентоносцев в Ирландии // Там же. - 1820. - Кн.9. - С.77-92. (Стиль и орфография наименования источника сохранены - примеч. автора)

${ }^{14}$ Неклюдов. Отличие заговора от тайного общества // Судебный вестник. - 1872. - №6. - С.5; Хохряков Н. О различии между тайным обществом и заговором по уложению о наказаниях // Юридический вестник. - 1872. - Август-Сентябрь. - С.1-23; Ордынский С. О преступных сообществах // Вестник права и нотариата. - 1909. - №3. - С.6.
}

${ }^{15}$ Пусторослев П.П. Государственные преступления относительно Государственной Думы // Вестник права. - 1906. - №2. - С.116.

${ }^{16}$ Анучин Е.Н. Исследование о проценте сосланных в Сибирь в период 1827-1846 годов. Материалы для уголовной статистики России. - СПб., 1873; Тарновский Е.Н. Статистические сведения о лицах, обвиняемых в преступлениях государственных // Журнал министерства юстиции. - 1905. - №4. - С.50-97; Его же. Изменения преступности в различных общественных группах // Юридический вестник. - 1889. - №5. - С.47-71; Его же. Статистика преступности лиц дворянского сословия // Вестник права. - 1890. - №9. - С.1441; Численность лиц, привлеченным к различным наказаниям за государственные преступления // Журнал министерства юстиции. и представителями отдельных политических партий. ${ }^{17} \mathrm{Ha}$ основе полученных данных каждые из них делали свои прогнозы. Одни - на будущее развитие политической жизни в российском обществе, другие - на состояние политической преступности в нем.

Во второй половине XIX века в российском обществе под воздействием объективных внешних и внутренних факторов активизировалась деятельность тайных организованных преступных сообществ, имевших целью с помощью противоправного вооруженного государственного переворота изменить существующий в империи государственный и общественный строй. ${ }^{18}$ Помимо подготовки к совершению вооруженного государственного переворота насильственным путем, тайные политические сообщества совершали организованные вооруженные общеуголовные преступления (бандитские нападения), направленные, как правило, на финансовое, материальное, информационное и иное обеспечение их деятельности, именовавшиеся участниками и организаторами этих преступлений - «эксами», а современными отечественными криминологами - политическим бандитизмом. ${ }^{19}$ По некоторым данным, только в период с января 1905 по июль 1906 года на территории Российской Империи было зарегистрировано 1951 крупное ограбление государственных учреждений, организаций, предприятий и частных хозяйствующих субъектов, в результате которых причинен огромный материальный ущерб интересам собственников и государства. ${ }^{20}$

В конце XIX - начале XX века стали появляться обстоятельные научные работы отечественных специалистов в области уголовного права, которые существенно повлияли на взгляды внутри российского общества по поводу оценки политической преступности и политических преступлений. Они стали рассматриваться отечественными

- 1915. - №4. - С.44; Численность лиц, привлеченным к различным наказаниям за государственные преступления // Тюремный вестник. - 1916. - №1. - С.43.

17 Ленин В.И. Роль сословий и классов в освободительном движении // Полн. Собр. Соч. - Т.23. - С.397-399; Его же. Из прошлого рабочей печати // Там же. - Т.25. - С.95.

${ }^{18}$ О противозаконных сообществах: Мнение Государственного Совета от 27 марта 1867 года // Журнал министерства юстиции. - 1867. - Т.32. - С.8-10; По поводу процесса 26-28 марта (редакционная статья) // Юридическое обозрение (Тифлис). - 1881. - №3. - С.65-67; Судебное разбирательство по поводу события 1 марта (Заседание особого присутствия правительствующего сената для суждения дел о государственных преступлениях // Там же. С.68-206; О бывшем студенте московского университета Иване Старынкевиче, обвиняемом в государственных преступлениях (редакционная статья) // Там же. - №16. - С.639; Правительственное сообщение // Юридическое обозрение. - 1883. - №108. - С.495-498.

${ }^{19}$ Российская политическая криминология: Словарь / Под общ. ред. П.А. Кабанова. - Нижнекамск, 2003. - С.14.

${ }^{20}$ Гейфман А.А. Сколько стоил боевизм // Родина. - 1998. - №7. - C.64. 
правоведами уже как специфичное негативное исторически изменчивое социально-правовое явление, представляющее собой совокупность (систему) уголовно-наказуемых деяний, совершенных по политическим побуждениям ${ }^{21}$ (целям или мотивам), ${ }^{22}$ а также лиц, их совершивших. Учитывая степень распространенности таких воззрений на проблему политических преступлений в российском обществе, данная дефиниция вошла на относительно небольшой промежуток времени в отечественное и право. ${ }^{23}$

Однако сводить всю политическую преступность, проявившуюся в российском обществе в период с IX по XX века, только к криминальному политическому насилию было бы неразумно. Помимо криминального политического насилия в политической сфере жизни общества существовали и противоправные политические деяния, совершаемые без применения насилия - путем обмана и/или злоупотребления властью. Хотя о степени их распространенности современные исследователи довольно редко упоминают, а специальных криминологических исследований данного феномена до настоящего времени не проводилось. По-видимому, в недалеком будущем отечественным исследователям в области политической криминологии придется проанализировать наиболее крупные исторические работы, посвященные анализу развития российской государственности и ее институтов, для поиска в них документов и материалов, свидетельствующих о степени распространенности и трансформации криминального политического мошенничества в российском обществе. Даже беглый взгляд на некоторые из них позволяет сделать определенные выводы и предположения по исследуемой проблеме.

Так, известный отечественный исследователь истории российского государства С.М. Соловьев, ссылаясь на жалобу подьячего на одного из воевод, который в 1673 году «... земских старост к мирским соборам и целовальников и приставов и иных рушников нам мирским людям выбирать не давал, выбирал сам собою тех, кто ему больше даст». ${ }^{24}$ В другом месте своего исследования автор, ссылаясь на архивные материалы и описывая более поздний период российской истории, указывает следующее: «В

\footnotetext{
${ }^{21}$ Маклаков В.А. На кого распространяется амнистия 21-го октября // Право. - 1905. - №45-46. - С.3690.

22 Лоховицкий А. Курс уголовного права: Преступления государственные // Журнал министерства юстиции. - 1867. - Т.33. - Приложение. - С.324; Тагер А.С. Политическая амнистия // Вестник права. - 1917. - №18. - С.365; Таганцев Н.С. Русское уголовное право. Лекции. Часть общая. В 2-х томах. - М., 1994. - Т.1. - С.139.

${ }^{23}$ Постановление Временного Правительства России от 6 марта 1917 года «Об амнистии» // Вестник пенитенциарных знаний. 1917. - №1-6. - C.30.

${ }^{24}$ Соловьев С.М. История России с древнейших времен. - М.,
} 1964. - T.13. - Кн.7. - С.92.
Ваневе земский староста с товарищами от ставили от сборов выборных своих таможенных и кабацких бурмистров за то, что они не давали денег, выбрали других, которые дали им 120 рублей». ${ }^{25}$

Приведенные С.М. Соловьевым факты свидетельствуют о том, что выборные местные органы государственной власти и их должностные лица в Российской Империи еще в XVII веке в условиях бесконтрольности со стороны уполномоченных на то органов и должностных лиц или злоупотребления властью высшими должностными лицами этих органов власти выбирались с нарушением норм избирательного права, а результаты (итоги) выборов под воздействием актов коррупции - фальсифицировались. В связи с распространением указанных форм противоправного приобретения, распределения, сохранения и утраты власти в органах местного самоуправления городов законодатель предусматривал уголовную ответственность за их совершение по нормам об ответственности за служебные (должностные) коррупционные преступления. В результате значительного распространения в российском обществе и за рубежом данных форм противоправного поведения появился новый вид политических правонарушений и преступлений, названный зарубежными современниками политологическим термином - электоральные. ${ }^{26}$ Как следствие такой уголовно-правовой оценки деяний, сопряженных с нарушением порядка в избирательном процессе, появился новый вид политической преступности, получивший в более поздний период название - электоральная преступность. ${ }^{27}$ Однако сразу же следует оговориться, что в тот период электоральная преступность порицалась с позиции российского уголовного закона только лишь в самой примитивной и наиболее распространенной форме - электоральной коррупции, то есть в «покупке» выборной должности в органах городского самоуправления. Однако, по мнению B.В. Астанина, данная форма коррупции, как и коррупционное поведение выборных должностных лиц органов местного самоуправления в российских городах, были

\footnotetext{
${ }^{25}$ Там же. - C.591.

${ }^{26}$ Ломброзо Ч., Ляски Р. Политическая преступность и революция по отношению к праву, уголовной антропологии и государственной науке / В переводе К.К. Толстого. В двух частях. - СПб., 1906. - C.207.

${ }^{27}$ Груздева А.П. Электоральная преступность: понятие и некоторые формы ее проявления в современной России // Вопросы национальной безопасности в исследованиях правоведов: Сборник научных трудов / Под ред. Г.Н. Горшенкова. - Сыктывкар, 2000. - С.95-102; Климова Ю.Н. Электоральная преступность: место в криминологической науке // Журнал о выборах (приложение к Вестнику ЦИК РФ). - 2003. - №2. - С.16-18; Ее же. Электоральная преступность: понятие и проблема ее сдерживания уголовно-правовыми сред-
} ствами // Следователь. - 2003. - №11. - С.45-48 и др. 


\section{Право и политика $2(158) \cdot 2013$}

незначительными по сравнению со степенью распространенности коррупционного поведения назначаемых от имени главы государства должностных лиц в региональные органы государственной власти. ${ }^{28}$

Отечественными историками отмечается, что в древние времена российское общество считало уместным применение к «проигравшим» в политическом противостоянии противникам любые меры наказания вплоть до политической смерти. Политическая смерть заключалась в лишении осужденных собственности, доброго имени, бессрочном лишении политических, семейных и гражданских прав, что дополнительно сопровождалось, как правило, лишением свободы или высылкой (ссылкой) в определенные регионы империи или лишением жизни. Однако к началу XX века взгляды соотечественников на уголовную ответственность и наказание за политические преступления и иные политические акции существенно изменились. Всякое чрезмерное или неадекватное реальной угрозе воздействие со стороны органов государственной власти и их должностных лиц в отношении субъектов политической деятельности стало именоваться политическими репрессиями и относиться к противоправному и уголовно-наказуемому злоупотреблению властью. ${ }^{29}$

Однако сразу же следует оговориться, что во второй половине XIX века и начале XX в российском обществе наиболее распространенным видом политической преступности был политический терроризм, проявлявшийся в форме политических убийств видных государственных и общественных деятелей Российской Империи. ${ }^{30}$ По некоторым данным, только за относительно небольшой по историческим меркам период времени, с 1 июня 1881 года по 1 января 1888 года, на территории Российской Империи департаментом полиции было зарегистрировано 1500 уголовных дел по фактам совершения актов политического терроризма в отношении 3046 человек. ${ }^{31}$ В последующем количество регистрируемых фактов политического терроризма постоянно увеличивалось. Вместе с этим увеличивалось и количество жертв политического терроризма. По данным профессора А. Гейфмана, в Российской Империи за период с 1901 по 1911 гг. от рук террористов погибло около 17 тысяч человек жертв политического терроризма, ${ }^{32}$

\footnotetext{
${ }^{28}$ Астанин B.В. Борьба с коррупцией в России XVI-XX веков: диалектика системного подхода. - М., 2003. - С.10.

${ }^{29}$ Гессен В.М. Юридическая оценка событий 9 января 1905 года // Вестник права. - 1905. - №1. - С.260-264.

${ }^{30}$ Суворов А.И. Политический терроризм в России XIX - начала $\mathrm{XX}$ веков. Истоки, структура, особенности // Социологические исследования. - 2002. - №7. - С.54-61.

${ }^{31}$ Хлебников И. Борьба с терроризмом. Из истории международного сотрудничества // Юридическая газета. - 1998. - №10. - С.3.

32 Гейфман А. Революционный террор в России. 1894-1917. - М., 1997. - C.32.
}

еще большее количество людей получило телесные повреждения различной степени тяжести, моральный и материальный вред.

Анализ статистических данных за период со второй половины XIX века по 1917 год и материалов научных исследований отечественных специалистов, характеризующих состояние политической преступности в этот сложный период, позволяют сделать некоторые выводы. Во-первых, в рассматриваемый нами период в российском обществе происходила эскалация политического насилия, как со стороны оппозиционных политических сил, так и со стороны государственных органов власти и их должностных лиц. Во-вторых, эта эскалация противоправного политического насилия внутри российского общества вылилась как закономерное и неизбежное следствие в ослабление органов государственной власти всех уровней и октябрьский вооруженный мятеж, закончившийся государственным переворотом.

Изменение формы правления в России в результате успешно проведенного большевиками противоправного насильственного вооруженного захвата власти не изменило социальной сущности политической преступности, оно лишь трансформировало ее правовое содержание под партийные и личные интересы новой правящей политической элиты. Все противоправные деяния, направленные против ранее существовавшего политического строя и его представителей, признавались общественно полезной деятельностью, а всякая деятельность, не вписывающаяся в рамки программных документов ВКП (б), считалась политически вредной (контрреволюционной) и подлежала уголовному преследованию. Бывшие политические преступники, пришедшие во власть, не желая отождествлять свою деятельность по насильственному захвату власти с политической преступной деятельностью, стали именовать себя революционерами, а своих политических оппонентов, не согласных с такой оценкой их деятельности, - контрреволюционерами. ${ }^{33}$

В результате замены правящей политической элитой правовых дефиниций «политическое преступление» и «политический преступник» на идеологические термины, произошло их постепенное вытеснение из правового лексикона, как и криминологической категории «политическая преступность». Эти категории в период становления советской власти, хотя и редко, но использовались большевиками в некоторых документах ведомственного и международного характера. ${ }^{34}$ Такой подход к оценке

\footnotetext{
${ }^{33}$ Кулаков А.Ф. Политическая преступность: криминологический и правовой аспекты: Дисс. ... кандид. юрид. наук. - Рязань, 2002. - C.17.

${ }^{34}$ См., например: Уголовный кодекс: Текст с постатейно систематизированными материалами законодательного и ведомственного характера / Предисл. Д.И. Курбского. - М., 1924. - С.24-27.
} 
политико-правовых событий прошлого и настоящего, а также неэффективное социальное управление экономическими и политическими процессами, совместно с другими объективными и субъективными факторами, создали социальную и политическую напряженность в российском обществе. Под воздействием указанных факторов в советском обществе происходили массовые протесты населения, перераставшие в вооруженные восстания и мятежи против органов власти Советского государства и их представителей. По некоторым данным, только в одном 1929 году на территории Советского Союза было зарегистрировано 13000 вооруженных мятежей населения в ответ на необоснованные притеснения должностными лицами органов государственной власти. ${ }^{35} \mathrm{~B}$ ответ на подобную реакцию общества лица, пришедшие во власть с помощью криминального политического насилия, ради ее сохранения и противоправного распределения внутри государства и общества стали теми же противоправными насильственными методами управлять Советским государством. Начавшись «красным террором», как вынужденной мерой противодействию политическому насилию, массовый террор превратился из орудия борьбы с «политическими преступниками» и политическими оппонентами в инструмент социального управления. ${ }^{36} \mathrm{~B}$ период существования Советского государства политическая преступность в нем под воздействием новых объективных и субъективных причин трансформировалась в более сложный вид. Она стала носить организованный характер и имела ярко выраженную антинародную направленность, проявлявшуюся в массовых политических репрессиях граждан Советского государства со стороны органов государственной власти и их должностных лиц с использованием всех имеющихся государственных ресурсов. Этому виду организованной политической преступности профессором В.С. Устиновым было дано название - тоталитарная преступность. ${ }^{37}$ Однако и в тоталитарном советском государстве политическая преступность проявлялась не только в противоправных деяниях правящей политической элиты. Отдельные деликты, направленные против основ советского государства и его отдельных должностных лиц в виде террористических актов и диверсий, объективно существовали, хотя и причиняемый

\footnotetext{
${ }^{35}$ Баранцева Е.Л. К вопросу о насилии как системообразующем факторе Советского государства // Научный вестник Кировского филиала Московского гуманитарно-экономического института. 2001. - №6. - C.125.

${ }^{36}$ Более подробно о государственном политическом терроре в Советском государстве см.: Лунеев В.В. Политическая преступность в России: прошлое и современность // Общественные науки и современность. - 1999. - №5. - С.66-79 и др.

${ }^{37}$ Устинов В.С. Понятие и криминологическая характеристика организованной преступности: Лекция. - Н. Новгород, 1993. - С.14.
}

ими вред обществу казался мизерным в соотношении с массовым государственным террором. Для обозначения этой группы однородных преступлений законодателем был использован нейтральный уголовно-правовой термин, не связанный с мотивацией и целеполаганием преступного поведения - государственные преступления, в результате чего отечественная криминология обогатилась новым термином - «государственная преступность», который активно используется современными криминологами. ${ }^{38}$

Созданию Советского тоталитарного государства предшествовало совершение тяжкого политического преступления - насильственного вооруженного захвата власти большевиками. Распаду этого государства способствовало аналогичное политическое преступление - попытка государственного переворота членами ГКЧП в августе 1991 года, но уже с целью насильственного сохранения советской политической системы и порядка распределения в ней государственной власти. ${ }^{39}$ Можно предположить, что целая эпоха в жизни российского государства, начавшаяся с совершения политического преступления и окончившаяся совершением аналогичного преступления, проходила под воздействием политической преступности. Безусловно, это не могло не сказаться на качественных и количественных характеристиках политической преступности постсоветского периода на территории России и поведении высших должностных лиц Российской Федерации, бывших активных функционеров КПСС, в одночасье провозгласивших себя демократами. Криминальное политическое насилие, использовавшееся советскими партийными и государственными руководителями в качестве средства управления государством и обществом, вместе с отдельными лидерами как наследие тоталитарного прошлого перешло в постсоветскую политическую деятельность руководителей российского государства.

Реформирование политической системы российского общества в октябре 1993 года переросло в противоправное применение насилия конфликтующими сторонами: главы государства (Президента России Б.Н. Ельцина) и высшего законодательного органа - Верховного Совета РСФСР. Здесь, на наш взгляд, применение политического насилия преследовало цель не только системного реформирования российской государственности. На наш взгляд, оно преследовало желание Президента России не столько сохранить, сколько значительно укрепить свою личную власть в обновляющемся российском государстве и обществе.

\footnotetext{
${ }^{38}$ Дьяков С.В. Государственные преступления (против основ конституционного строя и безопасности государства) и государственная преступность. - М., 1999.

${ }^{39}$ Топорнин Б.Н., Барабашев Г.В., Лившии Р.З., Шермет К.Ф. Августовский путч: последствия и уроки // Советское государство и право. - 1991. - №10. - С.9-19.
} 


\section{Право и политика 2 (158) 2013}

Распад Советского государства сопровождался «парадом суверенитетов» субъектов Российской Федерации и слабая, неокрепшая власть главы российского государства и его исполнительных органов объективно не могла противопоставить этому ни каких контрмер, а занялась нормотворчеством и решением неотложных и текущих дел по реформированию всех сфер социальной жизни. Через некоторое время руководителям российского государства стало ясно, что для восстановления хотя бы части былого влияния на международной арене необходима консолидация сил внутри российского государства и общества. Они попытались с использованием договорных процессов централизовать власть, то наткнулись не только на непонимание, но и явное нежелание лидеров субъектов Российской Федерации делится индивидуально или коллективно «приватизированной» ими властью в регионе с федеральным центром. Время было упущено. Для демонстрации иллюзии силы в соответствии с Указом Президента России в наиболее «суверенную» Чеченскую Республику без согласования с главой этой республики Д. Дудаевым были введены российские войска для обеспечения контроля над руководителями самопровозглашенной независимой «Республики Ичкерия» и смещения действующего главы. В результате этой военно-политической акции была спровоцирована так называемая «первая чеченская война». Политические и криминологические последствия этой политической акции устрашения в современном российском обществе до сих пор еще не оценены, да и не осознаны. Однако очевидно, что данное политическое вооруженное противостояние в Чеченской Республике детерминировало в последующем значительную долю политических преступлений в Северо-Кавказском регионе, в первую очередь, террористической направленности. Безусловно, эти трагические события в значительной мере влияют, и ещё долго будут влиять, на состояние политической преступности в России в будущем.

Историко-правовой и политико-криминологический анализ научных воззрений о политической преступности и политических преступлениях в России позволяет нам сделать некоторые выводы.

Во-первых, политическая преступность как социально-политическое и политико-криминологическое явление сопровождает всю историю развития России. Видоизменяясь на различных этапах существования российского государства, она, под воздействием различных групп социальных факторов, приспосабливаясь к новым условиям, продолжала активно влиять на политическую жизнь общества.

Во-вторых, в разное время на территории российского государства под воздействием различных социальных факторов активно проявляются и отражаются в официальной государственной статистике одни виды политической преступности и затихают (угасают) на время другие, «тлея»в глубине политической жизни, чтобы под воздействием политических страстей «вспыхнуть» вновь.

В-третьих, в разные исторические периоды российским законодателем, правоприменителем и научным сообществом вкладывается различный смысл в содержание терминов «политическое преступление» и «политическая преступность». Содержание этих понятий, чаще всего, определялось влиянием политических пристрастий руководителей государства и их окружения, чем правовыми нормами и доктринами.

Разумеется, высказанные в настоящей работе выводы не претендуют на окончательность и бесспорность. Они лишь в самом общем виде представляют собой одну из многих возможных точек зрения по проблеме существования и трансформации (изменения) политической преступности и суждений об этом феномене в российском обществе на протяжении его развития.

\section{Библиография:}

1. Анучин Е.Н. Исследование о проценте сосланных в Сибирь в период 1827-1846 годов. Материалы для уголовной статистики России. - СПб., 1873.

2. Баранцева Е.Л. К вопросу о насилии как системообразующем факторе Советского государства // Научный вестник Кировского филиала Московского гуманитарно-экономического института. - 2001. - №6.

3. Боатар. Лекции по уголовному праву и судопроизводству. Книга 3: Преступления против общества и государства / Пер. с франц. // Судебный журнал. - 1875. - Сентябрь - Октябрь.

4. Викторский Е.П. История смертной казни в России и современное её состояние. - М., 1912.

5. Владимирский-Буданов М.Ф. Обзор истории русского права. - Ростов - на - Дону, 1995.

6. Галкин Е.Б. Некоторые историко-социальные черты российской монархии // Социологические исследования. - 1998. - №5.

7. Гейфман А. Революционный террор в России. 18941917. - М., 1997.

8. Гейфман А.А. Сколько стоил боевизм // Родина. 1998. - №7.

9. Гессен В.М. Юридическая оценка событий 9 января 1905 года // Вестник права. - 1905. - №1.

10. Гроссе $Ф$. К вопросу о природе политических преступлений // Проблемы марксизма. Сборник второй: Проблема преступности / Под ред. и с предисловием Я.С. Розанова. - Киев, 1924.

11. Груздева А.П. Электоральная преступность: понятие и некоторые формы ее проявления в современной России // Вопросы национальной безопасности в ис- 
следованиях правоведов: Сборник научных трудов / Под ред. Г.Н. Горшенкова. - Сыктывкар, 2000.

12. Дьяков С.В. Государственные преступления (против основ конституционного строя и безопасности государства) и государственная преступность. - М., 1999.

13. Есипов В.В. Уголовное уложение 1903 года, его характер и содержание. - Варшава, 1903.

14. Есипов Г.В. Люди старого века. Разсказы из дел Преображенского Приказа и Тайной Канцелярии. СПб., 1880.

15. История государства и права СССР: Учебник. Часть 1 / Под ред. Ю.П. Титова. - М.,1988.

16. Как судить о всеобщих смятениях в Европе, а особенно в Англии? (Политический разговор) // Дух журналов или Собрание всего, что есть лучшего и любопытнейшего во всех других Журналах по части Истории, Политики, Законодательства, Правосудия, Государственного Хозяйства, Литтературы, разных Искусств, Сельского Домоводства и проч. - Кн.19.

17. Калашников И. Об устройстве судебно-уголовной власти в Греции и Риме. - СПб., 1850.

18. Карнович Е.П. Очерки наших порядков административных, судебных и общественных. - СПб., 1873.

19. Каутский К. Генезис политических преступлений // Проблемы марксизма. Сборник второй: Проблемы преступности / Под ред. и с предисловием Я.С. Розанова. - Киев, 1924.

20. Каутский К. Природа политических преступлений. - Киев, 1905.

21. Климова Ю.Н. Электоральная преступность: понятие и проблема ее сдерживания уголовно-правовыми средствами // Следователь. - 2003. - №11.

22. Кулаков А.Ф. Политическая преступность: криминологический и правовой аспекты: Дисс. ... кандид. юрид. наук. - Рязань, 2002.

23. Ленин В.И. Роль сословий и классов в освободительном движении // Полн. Собр. Соч. - Т.23.

24. Лист Ф. Международное право в схематическом изложении. - Юрьев, 1909.

25. Ломброзо Ч., Ляски Р. Политическая преступность и революция по отношению к праву, уголовной антропологии и государственной науке / В переводе К.К. Толстого. В двух частях. - СПб., 1906.

26. Лоховицкий А. Курс уголовного права: Преступления государственные // Журнал министерства юстиции. - 1867. - Т.33. - Приложение.

27. Лунеев В.В. Политическая преступность в России: прошлое и современность // Общественные науки и современность. - 1999. - №5.

28. Маклаков В.А. На кого распространяется амнистия 21-го октября // Право. - 1905. - №45-46.

29. Неклюдов. Отличие заговора от тайного общества // Судебный вестник. - 1872. - №6.
30. Никольский Д.П. О выдаче преступников по началам международного права. - СПб., 1884.

31. О мятежах лентоносцев в Ирландии // Дух журналов или Собрание всего, что есть лучшего и любопытнейшего во всех других Журналах по части Истории, Политики, Законодательства, Правосудия, Государственного Хозяйства, Литтературы, разных Искусств, Сельского Домоводства и проч. - 1820. - Кн.9.

32. О противозаконных сообществах: Мнение Государственного Совета от 27 марта 1867 года // Журнал министерства юстиции. - 1867. - Т.32.

33. Описание бунта бывшего в Китае в 1813 году // Дух журналов или Собрание всего, что есть лучшего и любопытнейшего во всех других Журналах по части Истории, Политики, Законодательства, Правосудия, Государственного Хозяйства, Литтературы, разных Искусств, Сельского Домоводства и проч. - 1819. Кн.10: Архив истории и политики.

34. Ордынский С. О преступных сообществах // Вестник права и нотариата. - 1909. - №3.

35. Постановление Временного Правительства России от 6 марта 1917 года «Об амнистии» // Вестник пенитенциарных знаний. - 1917. - №1-6.

36. Пусторослев П.П. Государственные преступления относительно Государственной Думы // Вестник права. - 1906. - №2.

37. Российская политическая криминология: Словарь / Под общ. ред. П.А. Кабанова. - Нижнекамск, 2003.

38. Соловьев С.М. История России с древнейших времен. - М., 1964. - Т.13. - Кн.7.

39. Суворов А.И. Политический терроризм в России ХІХ - начала XX веков. Истоки, структура, особенности // Социологические исследования. - 2002. - №7.

40. Таганцев Н.С. Русское уголовное право. Лекции. Часть общая. В 2-х томах. - М., 1994. - Т.1.

41. Тагер А.С. Политическая амнистия // Вестник права. - 1917. - №18.

42. Тард Г. Преступник и преступление. Сравнительная преступность. Преступления толпы / Сост. и предисл. В.С. Овчинского. - М., 2004.

43. Тарновский Е.Н. Изменения преступности в различных общественных группах // Юридический вестник. - 1889. - №5.

44. Тарновский Е.Н. Статистические сведения о лицах, обвиняемых в преступлениях государственных // Журнал министерства юстиции. - 1905. - №4.

45. Тельберг Г.Г. Система государственных преступлений в уложении Царя Алексея Михайловича // Журнал министерства юстиции. - 1911. - №5.

46. Топорнин Б.Н., Барабашев Г.В., Лившиц Р.3., Шермет К.Ф. Августовский путч: последствия и уроки // Советское государство и право. - 1991. - №10. 


\section{Право и политика 2 (158) 2013}

47. Устинов В.С. Понятие и криминологическая характеристика организованной преступности: Лекция. Н. Новгород, 1993.

48. Фейгин Я. Выдача политических преступников // Журнал гражданского и уголовного права. - 1884. - №4.

49. Х Хохряков Н. О различии между тайным обществом и заговором по уложению о наказаниях // Юридический вестник. - 1872. - Август-Сентябрь.

50. Штиглиц А.Ю. Исследования о выдаче преступников. - СПб., 1882.

\section{References (transliteration):}

1. Anuchin E.N. Issledovanie o protsente soslannykh v Sibir' v period 1827-1846 godov. Materialy dlya ugolovnoy statistiki Rossii. - SPb., 1873.

2. Barantseva E.L. K voprosu o nasilii kak sistemoobrazuyushchem faktore Sovetskogo gosudarstva // Nauchnyy vestnik Kirovskogo filiala Moskovskogo gumanitarnoekonomicheskogo instituta. - 2001. - №6.

3. Boatar. Lektsii po ugolovnomu pravu i sudoproizvodstvu. Kniga 3: Prestupleniya protiv obshchestva i gosudarstva / Per. s frants. // Sudebnyy zhurnal. - 1875. - Sentyabr' - Oktyabr'.

4. Viktorskiy E.P. Istoriya smertnoy kazni v Rossii i sovremennoe ee sostoyanie. - M., 1912.

5. Vladimirskiy-Budanov M.F. Obzor istorii russkogo prava. - Rostov - na - Donu, 1995.

6. Galkin E.B. Nekotorye istoriko-sotsial'nye cherty rossiyskoy monarkhii // Sotsiologicheskie issledovaniya. - 1998. - №5.

7. Geyfman A. Revolyutsionnyy terror v Rossii. 1894-1917. - M., 1997.

8. Geyfman A.A. Skol'ko stoil boevizm // Rodina. - 1998. - №7.

9. Gessen V.M. Yuridicheskaya otsenka sobytiy 9 yanvarya 1905 goda // Vestnik prava. - 1905. - №1.

10. Grosse F. K voprosu o prirode politicheskikh prestupleniy // Problemy marksizma. Sbornik vtoroy: Problema prestupnosti / Pod red. i s predisloviem Ya.S. Rozanova. - Kiev, 1924.

11. Gruzdeva A.P. Elektoral'naya prestupnost': ponyatie i nekotorye formy ee proyavleniya $\mathrm{v}$ sovremennoy Rossii // Voprosy natsional'noy bezopasnosti v issledovaniyakh pravovedov: Sbornik nauchnykh trudov / Pod red. G.N. Gorshenkova. - Syktyvkar, 2000.

12. D’yakov S.V. Gosudarstvennye prestupleniya (protiv osnov konstitutsionnogo stroya i bezopasnosti gosudarstva) i gosudarstvennaya prestupnost'. - M., 1999.

13. Esipov V.V. Ugolovnoe ulozhenie 1903 goda, ego kharakter i soderzhanie. - Varshava, 1903.
14. Esipov G.V. Lyudi starogo veka. Razskazy iz del Preobrazhenskogo Prikaza i Taynoy Kantselyarii. - SPb., 1880 .

15. Istoriya gosudarstva i prava SSSR: Uchebnik. Chast' $1 /$ Pod red. Yu.P. Titova. - M.,1988.

16. Kak sudit' o vseobshchikh smyateniyakh v Evrope, a osobenno v Anglii? (Politicheskiy razgovor) // Dukh zhurnalov ili Sobranie vsego, chto est' luchshego i lyubopytneyshego vo vsekh drugikh Zhurnalakh po chasti Istorii, Politiki, Zakonodatel'stva, Pravosudiya, Gosudarstvennogo Khozyaystva, Litteratury, raznykh Iskusstv, Sel'skogo Domovodstva i proch. - Kn.19.

17. Kalashnikov I. Ob ustroystve sudebno-ugolovnoy vlasti v Gretsii i Rime. - SPb., 1850.

18. Karnovich E.P. Ocherki nashikh poryadkov administrativnykh, sudebnykh i obshchestvennykh. - SPb., 1873.

19. Kautskiy K. Genezis politicheskikh prestupleniy // Problemy marksizma. Sbornik vtoroy: Problemy prestupnosti / Pod red. i s predisloviem Ya.S. Rozanova. - Kiev, 1924.

20. Kautskiy K. Priroda politicheskikh prestupleniy. - Kiev, 1905.

21. Klimova Yu.N. Elektoral'naya prestupnost': ponyatie i problema ee sderzhivaniya ugolovno-pravovymi sredstvami // Sledovatel'. - 2003. - №11.

22. Kulakov A.F. Politicheskaya prestupnost': kriminologicheskiy i pravovoy aspekty: Diss. ... kandid. yurid. nauk. - Ryazan', 2002.

23. Lenin V.I. Rol' sosloviy i klassov v osvoboditel'nom dvizhenii // Poln. Sobr. Soch. - T.23.

24. List F. Mezhdunarodnoe pravo v skhematicheskom izlozhenii. - Yur'ev, 1909.

25. Lombrozo Ch., Lyaski R. Politicheskaya prestupnost' i revolyutsiya po otnosheniyu k pravu, ugolovnoy antropologii i gosudarstvennoy nauke / V perevode K.K. Tolstogo. V dvukh chastyakh. - SPb., 1906.

26. Lokhovitskiy A. Kurs ugolovnogo prava: Prestupleniya gosudarstvennye // Zhurnal ministerstva yustitsii. - 1867 . - T.33. - Prilozhenie.

27. Luneev V.V. Politicheskaya prestupnost' v Rossii: proshloe i sovremennost' // Obshchestvennye nauki i sovremennost'. - 1999. - №5.

28. Maklakov V.A. Na kogo rasprostranyaetsya amnistiya 21-go oktyabrya // Pravo. - 1905. - №45-46.

29. Neklyudov. Otlichie zagovora ot taynogo obshchestva // Sudebnyy vestnik. - 1872. - №6.

30. Nikol'skiy D.P. O vydache prestupnikov po nachalam mezhdunarodnogo prava. - SPb., 1884.

31. O myatezhakh lentonostsev v Irlandii // Dukh zhurnalov ili Sobranie vsego, chto est' luchshego i lyubopytneyshego vo vsekh drugikh Zhurnalakh po chasti Istorii, Politiki, Zakonodatel'stva, Pravosudiya, Gosudarstvennogo Khozyaystva, Litteratury, raznykh Iskusstv, Sel'skogo Domovodstva i proch. -1820 . - Kn.9. 
32. O protivozakonnykh soobshchestvakh: Mnenie Gosudarstvennogo Soveta ot 27 marta 1867 goda // Zhurnal ministerstva yustitsii. - 1867. - T.32.

33. Opisanie bunta byvshego v Kitae v 1813 godu // Dukh zhurnalov ili Sobranie vsego, chto est' luchshego i lyubopytneyshego vo vsekh drugikh Zhurnalakh po chasti Istorii, Politiki, Zakonodatel'stva, Pravosudiya, Gosudarstvennogo Khozyaystva, Litteratury, raznykh Iskusstv, Sel'skogo Domovodstva i proch. -1819 . - Kn.10: Arkhiv istorii i politiki.

34. Ordynskiy S. O prestupnykh soobshchestvakh // Vestnik prava i notariata. - 1909. - №3.

35. Postanovlenie Vremennogo Pravitel'stva Rossii ot 6 marta 1917 goda «Ob amnistii» // Vestnik penitentsiarnykh znaniy. - 1917. - №1-6.

36. Pustoroslev P.P. Gosudarstvennye prestupleniya otnositel'no Gosudarstvennoy Dumy // Vestnik prava. - 1906. - №2.

37. Rossiyskaya politicheskaya kriminologiya: Slovar' / Pod obshch. red. P.A. Kabanova. - Nizhnekamsk, 2003.

38. Solov'ev S.M. Istoriya Rossii s drevneyshikh vremen. M., 1964. - T.13. - Kn.7.

39. Suvorov A.I. Politicheskiy terrorizm v Rossii XIX nachala KhKh vekov. Istoki, struktura, osobennosti // Sotsiologicheskie issledovaniya. - 2002. - №7.

40. Tagantsev N.S. Russkoe ugolovnoe pravo. Lektsii. Chast' obshchaya. V 2-kh tomakh. - M., 1994. - T.1.
41. Tager A.S. Politicheskaya amnistiya // Vestnik prava. 1917. - №18.

42. Tard G. Prestupnik i prestuplenie. Sravnitel'naya prestupnost'. Prestupleniya tolpy / Sost. i predisl. V.S. Ovchinskogo. - M., 2004.

43. Tarnovskiy E.N. Izmeneniya prestupnosti v razlichnykh obshchestvennykh gruppakh // Yuridicheskiy vestnik. 1889. - №5.

44. Tarnovskiy E.N. Statisticheskie svedeniya o litsakh, obvinyaemykh v prestupleniyakh gosudarstvennykh // Zhurnal ministerstva yustitsii. - 1905. - №4.

45. Tel'berg G.G. Sistema gosudarstvennykh prestupleniy v ulozhenii Tsarya Alekseya Mikhaylovicha // Zhurnal ministerstva yustitsii. - 1911. - №5.

46. Topornin B.N., Barabashev G.V., Livshits R.Z., Shermet K.F. Avgustovskiy putch: posledstviya i uroki // Sovetskoe gosudarstvo i pravo. - 1991. - №10.

47. Ustinov V.S. Ponyatie i kriminologicheskaya kharakteristika organizovannoy prestupnosti: Lektsiya. N. Novgorod, 1993.

48. Feygin Ya. Vydacha politicheskikh prestupnikov // Zhurnal grazhdanskogo i ugolovnogo prava. - 1884. - №4.

49. Khokhryakov N. O razlichii mezhdu taynym obshchestvom i zagovorom po ulozheniyu o nakazaniyakh // Yuridicheskiy vestnik. - 1872. - Avgust-Sentyabr'.

50. Shtiglits A.Yu. Issledovaniya o vydache prestupnikov. - SPb., 1882. 